\title{
§ 第13回秋季学術大会抄録 §
}

\section{1． 胃X線検査前処置法と成績について（第 2 報）}

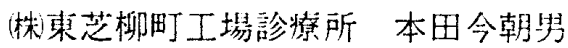
北緿白井病院放射線科青木 孝

\section{$[$ 目的]}

温水による婯易留洗浄は、海老根らによって報告されているが、我々は第38回柬京部会に於いて第

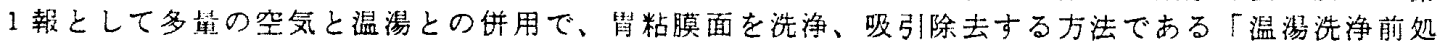

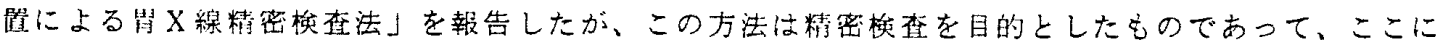
自然腊管流出量が多いことに着眼し、いかにしてスクリーニングに応用できるかを課题として検討を 加えた結果、この脂管流出量と時間の関俰を分析することによって、スクリーニング盟X線㭘查にお いても、筜小区描出に俥れた結果が得られているので報告する。

汹1は発泡郕と温湯による洗浄効果を表方すもので、困左の

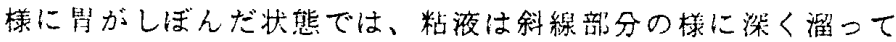
おり、これを発泡戍によって狊を過伸展状態に膨まし、粘膜の 溝を浅くして、粘液を洗い落し易く且つ最も刺漖の少ない温湯 によって洗浄する方法である。

[実 娩]

困 2 は洗浄液の晹管流出量と時問の関係を 5 例の平均で表わ したもので、発泡剂 $5 \mathrm{~g} と 45^{\circ} \mathrm{C}$ 温港 $300 \mathrm{~m} \ell$ を服用し、維時腈 管流出量を計量したものである。

計量法として再度温湯、発泡剂を徐々に服用し最初にマーキ

ングしたレべルに達したところで加減法によって計声した。 [方法]

(1)起床後、自宅に於いて発泡剂 $3 \sim 6 g$ を少量の水で服用、 "ゲッブ"を抑制。

(2) $45^{\circ}$ C 前後の温湯 $300 \mathrm{~m} \ell$ を飲用。

(3)疊の上で卧位になり左回転 5 回、右回転 5 回。

(4)立位で最大前屈 2 回。

(5)予䄪時間に来院、㛟查。

[結果]

今回対象としたものは、外来患者 163 例で年命、性別、蒴形 等による制限を加えず任意に描出した非前処置例 163 例の筲小 区描出率を等癌取扱規約のCMA分類で消化器専門医 2 名、放 射線技師 5 名で比較娭討した。

使用装置は東芝 D T-F V 、嶋津 Z S $-20 、 B a$ 漂度 $150 \% \mathrm{w} / \mathrm{v}$ を250〜 $300 \mathrm{~m} \ell$ 使用した。

表 1 の如く前処䈯群では、C 領域 $91 \%$ 、M 領域 $90 \%$ 、A 領域 $98 \%$ と明らかな胃小区描出率の向上が譛められた。特にC 領域 では非前処置群に比して、実に75\%の上界率で、小病变の見逃 し防止を計ることができた。

更に图 3 は本前処膡法の感想を被娭者にアンケートしたもの である。グラフより被㛟者の空腹感によるストレスの解消を蓇 づけるむのと言える。

[結誨]

(1)画像の向上。

(2)空腹感によるストレス解消。

(3)簡便である。

(4)洗海液の吸引除去が不要。

現在を外来に於いて本前処置法を継繶し娭討を重标ているか 今回迹中経過として報告した。更に入院患者を対象として実施 して晾り、第 3 報として報告予定である。

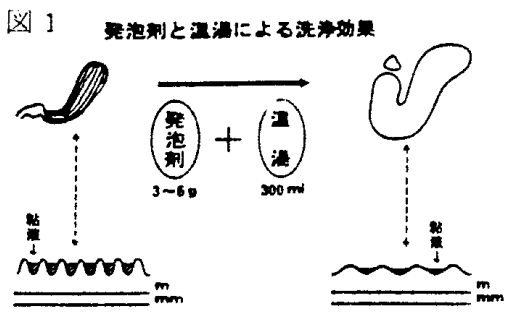

这 2

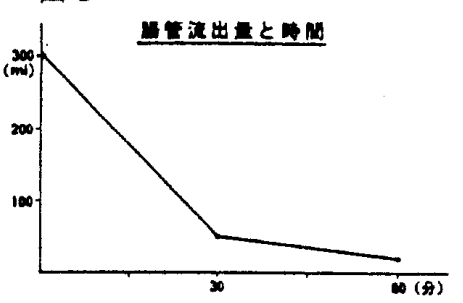

\begin{tabular}{|c|c|c|c|c|}
\hline & \multicolumn{2}{|c|}{ Rnemen (1003) } & \multicolumn{2}{|c|}{$\operatorname{manan}(105 n)$} \\
\hline & Dmantan & $=\max (x)$ & 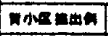 & $m \pm(x)$ \\
\hline $\cos x$ & 41 & 25.2 & 149 & 91.4 \\
\hline $\operatorname{minx}$ & 106 & 65.0 & 147 & $\$ 0.2$ \\
\hline Ana: & 122 & 74.8 & 160 & 28.1 \\
\hline
\end{tabular}

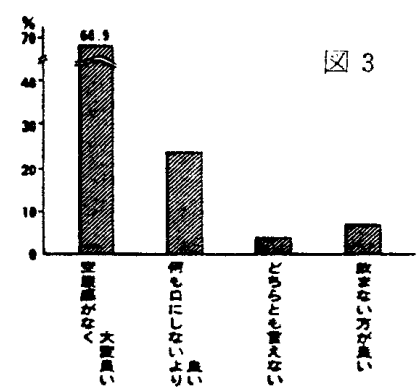

